\title{
Dostępność dzienna w układzie miast wojewódzkich w Polsce Daily accessibility among Poland's voivodeship cities
}

\author{
Ewa Garbacz ${ }^{1}$ (D) Tomasz Komornicki ${ }^{2}$ (D) Karol Kowalczyk ${ }^{1}$ (D) \\ ${ }^{1}$ Uniwersytet Marii Curie-Skłodowskiej w Lublinie \\ Wydział Nauk o Ziemi i Gospodarki Przestrzennej \\ al. Kraśnicka 2D, 20-718 Lublin \\ ${ }^{2}$ Instytut Geografii i Przestrzennego Zagospodarowania im. S. Leszczyckiego PAN \\ ul. Twarda 51/55, 00-818 Warszawa \\ ewa.garbacz@poczta.umcs.lublin.pl•t.komorn@twarda.pan.pl•karol.kowalczyk@poczta.umcs.lublin.pl
}

Zarys treści. Przedmiotem artykułu jest analiza poziomu dostępności dziennej w układzie miast wojewódzkich w Polsce, w kontekście ich potencjału do kształtowania wzajemnych powiązań funkcjonalno-przestrzennych. Pomiar dostępności dziennej wykonano na podstawie czasów przejazdu transportem indywidualnym (samochodowym) i kolejowym. Ponadto w analizie uwzględniono trzy warianty czasowe podróży jednodniowej (4, 6 i 8 godzin dostępnych w miejscu docelowym podróży). Pozwoliło to na utworzenie syntetycznego wskaźnika dostępności dziennej dla poszczególnych miast wojewódzkich, a następnie na sklasyfikowanie ich pod kątem możliwości kształtowania wzajemnych powiązań funkcjonalno-przestrzennych.

Słowa kluczowe: dostępność transportowa, dostępność dzienna, miasta wojewódzkie, powiązania funkcjonalne, metropolia sieciowa.

Keywords: transport accessibility, daily accessibility, voivodeship cities, spatial planning, metropolis network.

\section{Wstęp}

Policentryczny charakter układu osadniczego Polski oraz nasilające się w ostatnich latach procesy metropolizacji sprawiają, że coraz więcej uwagi poświęca się szeroko rozumianym powiązaniom funkcjonalnym. W roku 1995 D.F. Batten stwierdził, że sieć dwóch lub więcej miast o komplementarnych funkcjach, połączonych ze sobą za pomocą infrastruktury transportowej, w drodze wymiany wiedzy i kreatywności, może osiągać znaczne korzyści płynące z synergii działań. Przy czym zaznaczył, że dynamika wzrostu uzyskana w ramach współpracy sieciowej jest niewspółmiernie wyższa w porównaniu z działaniami podejmowanymi w pojedynkę. Powiązania funkcjonalne pomiędzy miastami wojewódzkimi Polski gwarantują większą spójność oraz przyczyniają się do wzrostu konkurencyjności gospodarki krajowej. Z tego względu problematyka niniejszego artykułu koncentruje się wokół zagadnień związanych z wzajemną dostępnością transportową największych ośrodków. Poprawa poziomu dostępności transportowej przyczynia się do pogłębienia powiązań funkcjonalno-przestrzennych, co stwarza korzystne warunki do rozwoju układu sieciowego polskich metropolii, a tym samym realizacji celów wskazywanych w Koncepcji Przestrzennego Zagospodarowania Kraju 2030 (szczegółowo opisanych zwłaszcza w wersji eksperckiej dokumentu - Korcelli i inni, 2010). 
Miasta wojewódzkie charakteryzujące się lepszą dostępnością transportową są bardziej atrakcyjne pod kątem inwestycyjnym. Wyższy poziom atrakcyjności inwestycyjnej wynika między innymi z większego kapitału ludzkiego, łatwiejszego dostępu do rynków zbytu, łatwiejszego przepływu kapitału i usług oraz przede wszystkim z oszczędności związanych z czasem i niższymi kosztami transportu. Kolejnym czynnikiem skłaniającym do podjęcia badań nad dostępnością w układzie miast wojewódzkich Polski, jest wysoka - w obecnych realiach - potrzeba realizowania jednodniowych podróży biznesowych. Z tego powodu do badań wykorzystano, znany z literatury przedmiotu, wskaźnik dostępności dziennej.

Celem głównym niniejszego opracowania jest próba określenia, czy i na ile obecny system drogowy oraz układ linii i połączeń kolejowych stwarza korzystne warunki do rozwoju układu sieciowego polskich metropolii. W ujęciu bardziej aplikacyjnym jest nim ocena (z punktu widzenia dostępności dziennej) stopnia wdrożenia, wzmiankowanej w dokumencie KPZK 2030, policentrycznej sieci metropolii (element celu 1 polityki zagospodarowania przestrzennego kraju; Koncepcja..., 2011, s. 81). W związku z powyższym autorzy dokonali próby określenia potencjału tworzenia się wzajemnych powiązań funkcjonalno-przestrzennych w układzie miast wojewódzkich Polski, stosując przy tym wskaźnik dostępności dziennej. W pierwszej kolejności dostępność dzienną przedstawiono w podziale na dwa analizowane typy transportu: indywidualny i kolejowy. Wyniki odniesiono do uwarunkowań płynących ze stanu infrastruktury i organizacji badanych gałęzi transportu, co pozwoliło na ukazanie szeregu zależności występujących w poszczególnych relacjach międzymiastowych. W dalszej części artykułu uzyskane wyniki zestawiono ze sobą i zaprezentowano w formie rankingu miast wojewódzkich, utworzonego na podstawie wielkości sumarycznego wskaźnika dostępności dziennej. Pozwoliło to na sformułowanie wniosków w kontekście możliwości rozwoju układu sieciowego polskich metropolii.

\section{Dotychczasowy stan badań w świetle literatury}

Literatura z zakresu dostępności transportowej oraz powiązań funkcjonalno-przestrzennych jest bardzo bogata. Według T. Kwarcińskiego (2012) samo pojęcie dostępności jest bardzo szerokie i uniwersalne. W rozumieniu Strategii Rozwoju Transportu do 2020 roku, dostępność transportowa oznacza „łatwość osiągania danego miejsca ze zbioru innych miejsc dzięki istnieniu sieci i usług transportowych". W literaturze przedmiotu funkcjonuje wiele wymiarów dostępności transportowej, między innymi: dostępność mierzona odległością, mierzona izochronami, mierzona wyposażeniem infrastrukturalnym, potencjałowa, spersonalizowana, mierzona maksymalizacją użyteczności (Geurs i van Eck, 2001; Geurs i van Wee, 2004; Komornicki i inni, 2010; Rosik, 2012; Stępniak i inni, 2013; Komornicki i Stępniak, 2015) oraz przedstawiona w niniejszym opracowaniu - dostępność dzienna.

Badania dostępności prowadzone są obecnie najczęściej jako element ewaluacji programów inwestycyjnych lub pod kątem jakości życia mieszkańców określonych obszarów. Analizy ewaluacyjne inwestycji transportowych w skali europejskiej prowadzone były początkowo głównie przez ośrodki niemieckie (Spiekermann i Schurmann, 2007), m.in. w ramach projektów ESPON (1.2.1., 2004; SeGI, 2012; TRACC, 2013; TRACC, 2015). Ponadto niektóre kraje (m.in. Hiszpania, Polska i Czechy) wykonują tego rodzaju badania dla swoich terytoriów (López i inni, 2008; także w kontekście międzynarodowym; Rosik i inni, 
2015). Jednocześnie liczni autorzy opisują dostępność w kategoriach równości (equity) lub sprawiedliwości (justice) przestrzennej (Komornicki, 2019). Najczęściej dotyczy to jednak obszarów miejskich (Kelobonye i inni, 2019; Nazari Adli i inni, 2019) lub też obszarów peryferyjnych i dostępu do określonych kategorii usług publicznych (Arranz-Lopez i inni, 2019; Wiśniewski i Komornicki, 2015; Stępniak i inni, 2017).

Koncepcja pomiaru dostępności dziennej wiąże się z podróżami biznesowymi bądź innymi, realizowanymi w trakcie jednego dnia. Pomiar dostępności dziennej polega na wyznaczeniu najwcześniejszej możliwej godziny wyjazdu, określeniu minimalnego czasu do wykorzystania w miejscu docelowym (niezbędnego np. do odbycia spotkania biznesowego) oraz wskazaniu najpóźniejszej godziny powrotu do miejsca początkowego. Jeżeli czas podróży w danym połączeniu międzymiastowym spełnia przyjęte kryteria, oznacza to, że w tej relacji występuje dostępność dzienna. Zastosowany w niniejszym opracowaniu sposób pomiaru bazuje na metodzie contactability, którą w 2013 r. opisał w swojej pracy Alain L'Hostis. Przykładem zastosowania tej metody były badania nad potencjalnym wpływem budowy dodatkowej linii kolejowej TGV, łączącej francuskie miasta Tours i Bordeaux, na poziom dostępności (L’Hostis i inni, 2017). Opisywany wskaźnik w nieco innej formie wykorzystywała Europejska Sieć Obserwacyjna Rozwoju Terytorialnego i Spójności Terytorialnej (ESPON TRACC, 2013), m.in. w badaniach dostępności dziennej miejsc pracy regionu Bawarii. W rozumieniu ESPON wskaźnik dostępności dziennej oznacza także liczbę osób, do której można dotrzeć w ciągu jednodniowej podróży oraz wyraża potencjał ekonomiczny danej lokalizacji. Wskaźnik dostępności dziennej w takiej formie wykorzystał również J. Gutierrez, który badał wpływ linii kolei dużych prędkości Madryt-Barcelonagranica Francji (Gutierrez, 2001). Literatura przedmiotu zawiera także szereg opracowań odnoszących się do koncepcji rozwoju układów policentrycznych oraz korzyści, jakie z nich wynikają (Kloosterman i Musterd, 2001; Meijers, 2007). W rozważaniach tych bardzo często analizowana jest sytuacja holenderskiego regionu Randstad, który przez wielu autorów uznawany jest jako modelowy przykład regionu policentrycznego (Batten, 1995; Meijers, 2005, 2007; Cowell, 2010). Nowsze prace wiążące rozwój policentryczny z dostępnością bazują najczęściej na doświadczeniach chińskich, co wiązać należy z ogromną skalą nowych projektów infrastrukturalnych w tym kraju (m.in. Jiao i inni, 2017; Zhao i inni, 2017) lub odnoszą się do mobilności w sieciach miast (np. w Bawarii; Starikova, 2018).

Nieliczne są badania dotyczące stricte dostępności dziennej w układzie miast wojewódzkich Polski. Wyniki takich badań nad dostępnością dzienną transportem indywidualnym i kolejowym dla Polski Zachodniej przedstawiono w ekspertyzie T. Komornickiego (2011). Z kolei koncepcją rozwoju sieciowego zajmował się R. Domański (2003; Domański i Marciniak, 2005). Rozważania nad policentrycznością w układzie polskich metropolii, a także nad dostępnością dzienną (transportem kolejowym), przedstawili T. Komornicki i inni (2013). Zagadnienie poruszano także w kontekście wartości czasu w transporcie (Ważna, 2013). Ponadto realizowane były badania powiązań między dużymi miastami w Polsce z wykorzystaniem innych pokrewnych metod, np. liczby kolejowych połączeń bezpośrednich w ciągu dnia lub tygodnia (Rydzewski, 2002) oraz różnic między średnią prędkością drogową i prędkością handlową w kolejowych połączeniach międzyaglomeracyjnych (Kowalczyk i Rosik, 2015). Tego typu analizę dla miast województwa łódzkiego realizował S. Wiśniewski (2015), a dla Szczecina - E. Chądzyńska (2014). 


\section{Metodyka badań}

Badania dostępności dziennej w układzie miast wojewódzkich w Polsce przeprowadzono na podstawie czasów przejazdu transportem indywidualnym i kolejowym. Początkowa koncepcja badań zakładała także analizę dostępności dziennej w transporcie autobusowym. Powodem, dla którego odstąpiono od tego typu badań, była niejednokrotnie konieczność uwzględniania połączeń z jedną (lub więcej) przesiadką. W wielu przypadkach, ze względu na różnych przewoźników obsługujących daną trasę, wiązałoby się to z koniecznością analizy kilku (bardzo często nieujednoliconych) rozkładów jazdy, co znacznie wydłużyłoby czas badań. Natomiast, jeżeli chodzi o samego podróżnego, wymagałoby to od niego zakupu oddzielnego biletu oraz niejednokrotnie zmiany przystanku w celu kontynuacji podróży, co mogłoby skutkować wydłużeniem czasu podróży i jednocześnie obniżeniem jej komfortu.

Dane dla transportu indywidualnego, odnoszące się do stanu z 2015 r., zaczerpnięto z bazy danych Instytutu Geografii i Przestrzennego Zagospodarowania PAN. Baza ta powstała podczas realizacji kolejnych analiz dostępności potencjałowej (czasy przejazdu były w jej wypadku istotnym elementem obliczania wartości wskaźnika; Komornicki i inni, 2018). Czasy w transporcie drogowym zostały wygenerowane na bazie modelu prędkości stosowanego w IGiPZ PAN. Jego wyjściową podstawą jest prędkość kodeksowa obowiązująca na poszczególnych rodzajach dróg. Prędkość ta jest redukowana z uwagi na: obecność obszaru zabudowanego (na podstawie zdjęć satelitarnych), liczbę ludności w buforze $5 \mathrm{~km}$ wokół drogi oraz przeciętne nachylenia terenu (ukształtowanie powierzchni; szczegóły modelu w publikacji T. Komornickiego i innych, 2010). Dane dla transportu kolejowego pozyskano z Elektronicznego Rozkładu Jazdy Pociągów, obowiązującego w październiku 2017 r. Zakres przestrzenny objął 16 miast wojewódzkich. W przypadku regionów z dwiema stolicami, wybrano odpowiednio: Bydgoszcz w województwie kujawsko-pomorskim i Zieloną Górę w lubuskim.

Dostępność dzienną zbadano w trzech wariantach czasowych: cztero-, sześcioi ośmiogodzinnym. Przy czym poprzez wariant czasowy rozumie się czas dostępny do dyspozycji podróżnego w miejscu docelowym realizowanej przez niego podróży. Istnienie dostępności dziennej transportem indywidualnym oznacza sytuację, w której dana osoba rozpoczyna swoją podróż punktualnie o godzinie 5:00, następnie w miejscu docelowym ma do dyspozycji 4, 6 lub 8 godzin, po czym wraca do miejsca początkowego podróży najpóźniej o godzinie 23:001․ Dostępność transportem indywidualnym badano w jednym kierunku, ponieważ dwukierunkowe czasy przejazdu zawarte w bazie danych są względem siebie symetryczne. Dostępność dzienną transportem kolejowym badano w analogiczny sposób, jednakże na podstawie rozkładu jazdy pociągów. Analizowano zarówno połączenia bezpośrednie, jak i z przesiadkami, uwzględniając najwcześniejsze, realizowane po godzinie 5:00, bądź późniejsze. W tym drugim przypadku musiały one spełniać dodatkowe kryterium, jakim był wcześniejszy dojazd do miejsca docelowego. W kierunku powrotnym brano pod uwagę połączenia umożliwiające przyjazd do miejsca początko-

${ }^{1}$ Zaproponowany przedział czasowy, tj. początek podróży-godzina 5:00, powrót - godzina 23:00 oraz czas dostępny w miejscu docelowym - 6 godzin, zaczerpnięto ze znanej z literatury przedmiotu metody contactability (L’Hostis i inni, 2017). Pozostałe warianty godzinowe, tj. 4 i 8 godzin do dyspozycji w miejscu docelowym podróży, dodano w celach poznawczych, jako opcje krótkiej i długiej podróży jednodniowej. 
wego przed 23:00. Zbadanie dostępności transportem kolejowym wymagało analiz obu kierunków, ponieważ czasy przejazdu w tej samej relacji, ale w przeciwne strony, często różniły się, co wynika ze specyfiki rozkładu jazdy.

Zebrane dane zestawione zostały w postaci macierzy czasów przejazdu. Zważywszy na przyjęte kryteria, odnoszące się do godzin rozpoczęcia oraz zakończenia podróży, a także znając długości podróży w obu kierunkach, obliczono czas do dyspozycji w poszczególnych miejscach docelowych. Możliwe było dzięki temu sprawdzenie, w ilu wariantach czasowych w danej relacji spełnione zostały kryteria dostępności dziennej. Na podstawie uzyskanych wielkości sporządzono ranking łączny, który posłużył do ostatecznej syntezy wyników badań. Polegało to na utworzeniu macierzy, w której zamieszczono zsumowaną liczbę wariantów spełniających kryteria dostępności dziennej w danej relacji. Zastosowaną metodę można utożsamiać z prostą bonitacją, w której dłuższy czas pobytu w mieście docelowym „waży” więcej niż krótszy. O ile dostępność dzienna dla każdego z przyjętych wariantów jest wielkością zero-jedynkową (dostępność ma miejsce lub nie), to wartość sumaryczna jest już wskaźnikiem obrazującym stopnie dostępności w ramach zbioru pojedynczych relacji oraz, po agregacji, w zbiorze 16 ośrodków miejskich.

\section{Charakterystyka i uwarunkowania transportu indywidualnego i kolejowego w Polsce}

Na czasy przejazdu pomiędzy miastami wojewódzkimi wpływa wiele czynników zarówno o charakterze jakościowym, jak i ilościowym. Ze względu na wyraźne zróżnicowanie przestrzenne gęstości oraz jakości sieci drogowej i kolejowej, podczas badań dostępności dziennej między polskimi miastami wojewódzkimi zwrócono szczególną uwagę na czynniki wynikające ze stanu infrastruktury. Było to także niezbędne przy późniejszym formułowaniu wniosków dotyczących występowania dostępności dziennej w poszczególnych relacjach oraz poziomu wskaźnika sumarycznego dla poszczególnych ośrodków wojewódzkich.

Transport indywidualny (samochodowy) jest najszybciej rozwijającą się gałęzią transportu w Polsce. Według Strategii Rozwoju Transportu do 2020 roku (z perspektywą do 2030 roku) (2013), dynamiczny rozwój transportu indywidualnego spowodowany jest przede wszystkim znacznym wzrostem liczby samochodów osobowych (o 53\% w roku 2010 w stosunku do roku 2003), a także intensyfikacją ich wykorzystania. W 2010 r. popyt na transport indywidualny stanowił 78,2\%, przy czym strategia ta zakłada, że do 2020 r. udział tego sektora w transporcie ogółem wzrośnie do ok. 82\%. Czynnikiem koniecznym do efektywnego przemieszczania się transportem indywidualnym jest odpowiednia infrastruktura, w tym przypadku drogi szybkiego ruchu. W Polsce na koniec 2017 r. istniało 422,3 tys. km dróg publicznych, z czego 1637 km stanowiły autostrady i 1768 km drogi ekspresowe. W stosunku do roku 2010 oznacza to ponad dwukrotny wzrost długości dróg szybkiego ruchu (GUS, 2011, 2017). Intensywny rozwój sieci drogowej związany jest przede wszystkim z wykorzystaniem środków pochodzących z programów pomocowych Unii Europejskiej. Z punktu widzenia poprawy powiązań między miastami wojewódzkimi najistotniejsze inwestycje okresu 2004-2017 objęły budowę następujących odcinków (GDDKiA, 2020):

- autostrada A1: Łódź - Stryków - Pruszcz Gdański (ukończenie 2008-2014);

- autostrada A2: Konin - Stryków - Warszawa (w. Konotopa) (2012); 
- autostrada A4: Kraków - Rzeszów (2009-2013);

- droga ekspresowa S3: Zielona Góra - Gorzów Wielkopolski - Szczecin (2010-2017);

- droga ekspresowa S5: Wrocław - Leszno (2014-2017);

- droga ekspresowa S7: Elbląg - Olsztyn (S51) - granica woj. warmińsko-mazurskiego; Grójec - Radom - Kielce - granica woj. świętokrzyskiego (2007-2017);

- droga ekspresowa S8: Białystok - północna obwodnica Warszawy - w. Lotnisko; w. Radziejowice - Piotrków Trybunalski; Łódź - Wrocław (2008-2017);

- droga ekspresowa S17: Lublin - Kurów (2013-2014).

Z punktu widzenia niniejszej analizy istotne są odcinki zrealizowane do końca roku 2015 (jako te które znalazły się w wykorzystywanej bazie czasów przejazdów pochodzącej z zasobów IGiPZ PAN). Program Budowy Dróg Krajowych na lata 2014-2023 zakłada dalsze zwiększenie gęstości dróg ekspresowych i autostrad z 8,7 km/1000 km² do $17,5 \mathrm{~km} / 1000$ km². Jednym z jego celów szczegółowych jest między innymi poprawa spójności sieci dróg krajowych, a co za tym idzie wzmocnienie efektywności transportu drogowego. Według założeń realizacja tego celu ma przełożyć się na skrócenie średniego czasu podróży pomiędzy ośrodkami wojewódzkimi o co najmniej 15\% w stosunku do czasów przejazdu odnotowanych w 2013 r. Ma to istotne znaczenie w kontekście potencjalnej poprawy poziomu dostępności dziennej miast wojewódzkich, gdyż rozkład przestrzenny dróg szybkiego ruchu w Polsce nie jest jeszcze równomierny.

Transport kolejowy jest drugą co do wielkości gałęzią transportu na terenie kraju, świadczącą usługi w przewozach pasażerskich i towarowych. Z danych statystycznych Urzędu Transportu Kolejowego (UTK, 2019) wynika, że liczba podróżnych w przewozach pasażerskich wykazuje w ostatnich latach tendencję wzrostową, a na znaczeniu zyskują w szczególności międzyaglomeracyjne przewozy dalekobieżne. W 2017 r. z usług kolei skorzystało 303,6 mln podróżnych, co w porównaniu z rokiem 2015 oznacza ponad 8,3\% wzrost. Według M. Falkowskiego i M. Pytla (2014), mimo wzrostu liczby pasażerów, infrastruktura kolejowa w Polsce jest wciąż przestarzała i pod względem jakości w znaczny sposób odbiega od standardów europejskich. Problem ten dotyczy w szczególności odcinków o znaczeniu regionalnym oraz częściowo występuje na liniach łączących miasta wojewódzkie. Zrealizowane w latach 2004-2017 inwestycje współfinansowane ze środków Unii Europejskiej wpłynęły na znaczącą poprawę stanu (modernizację) kilku odcinków magistralnych. Największe przedsięwzięcia tego typu objęły linie (PLK, 2020):

- nr 1, nr 17: Warszawa - Łódź (ukończenie 2008-2017);

- nr 6/E 75: Warszawa - Tłuszcz - Sadowne, w kierunku Białegostoku (2015-2017);

- nr 9/E 65: Warszawa - Gdynia (2006-2017);

- nr 91/E 30: Kraków - Rzeszów (2015-2016);

- nr 271/E 59: Wrocław - granica woj. dolnośląskiego, w kierunku Poznania (2014-2016).

Ogólnokrajowy efekt przeprowadzonych prac modernizacyjnych i rewitalizacyjnych jest jednak mniej spektakularny aniżeli w przypadku nowo wybudowanych dróg ekspresowych i autostrad. Dopiero koniec perspektywy finansowej 2014-2020 ma szansę przynieść wyraźną poprawę w relacjach kolejowych między pozostałymi miastami wojewódzkimi. Odrębnym problemem przekładającym się na dostępność transportu kolejowego w Polsce jest nierównomierne rozmieszczenie sieci w poszczególnych regionach, będące skutkiem czynników historycznych. Sieć istniejąca w obecnych granicach Polski przez pierwsze kilkadziesiąt lat (począwszy od 1842 r.) rozwijała się pod rządami trzech 
zaborów, reprezentujących odmienne podejścia planistyczne. W 2 poł. XX w. i na początku XXI w. nastąpił natomiast proces regresu sieci, przejawiający się likwidacją lokalnych odcinków, który częściowo zmniejszył występujące pierwotnie międzyregionalne różnice gęstości (Taylor, 2007; Rosik i inni, 2017). Według danych GUS za 2017 r. uśredniona gęstość linii kolejowych w Polsce wynosi 6,1 km/100 km² (według Z. Taylora w $1980 \mathrm{r}$. było to $8,7 \mathrm{~km} / 100 \mathrm{~km}^{2}$ ). W układzie regionalnym najwyższy wskaźnik gęstości występuje w województwie śląskim $\left(15,8 \mathrm{~km} / 100 \mathrm{~km}^{2}\right)$, co wiąże się z obecnością na tym terenie również sieci kolei przemysłowych. Znaczący poziom gęstości występuje także w województwach: dolnośląskim $\left(8,7 \mathrm{~km} / 100 \mathrm{~km}^{2}\right)$, opolskim $\left(8,2 \mathrm{~km} / 100 \mathrm{~km}^{2}\right)$ i małopolskim (7,1 km/100 km²). Najsłabiej wypadają województwa położone we wschodniej części kraju: lubelskie $\left(4,2 \mathrm{~km} / 100 \mathrm{~km}^{2}\right)$ oraz podlaskie $\left(3,6 \mathrm{~km} / 100 \mathrm{~km}^{2}\right)$.

\section{Wyniki badań dostępności dziennej w układzie miast wojewódzkich w Polsce}

W pierwszej kolejności scharakteryzowane zostały rezultaty badań dostępności dziennej w transporcie indywidualnym, które zestawiono w formie macierzy w tabeli 1. Uzyskane wyniki pokazały, że miastami, które posiadają najkorzystniejsze warunki do odbywania podróży jednodniowych transportem indywidualnym, są Łódź i Warszawa. We wszystkich relacjach z innymi miastami wojewódzkimi oraz we wszystkich przebadanych wariantach czasowych wystąpiła w przypadku tych dwu miast dostępność dzienna. Kolejnymi dobrze skomunikowanymi pod tym kątem miastami są Poznań i Bydgoszcz, które na 90 możliwych relacji posiadały kolejno 88 i 84 z dostępnością dzienną. Tak wysoki poziom wskaźnika dostępności dziennej transportem indywidualnym wśród wymienionych miast wynika niewątpliwie z korzystnej lokalizacji względem pozostałych ośrodków, a także z położenia na trasie głównych szlaków komunikacyjnych o charakterze krajowym (autostrada A1 i A2) i europejskim (sieć TEN-T). Miastami charakteryzującymi się najniższym poziomem wskaźnika dostępności dziennej transportem indywidualnym okazały się być Szczecin i Rzeszów. W przypadku obu stolic województw, w trzech przebadanych wariantach czasowych, kolejno w 62 i 64 relacjach wystąpiła dostępność dzienna. W ujęciu procentowym oznacza to, że spośród wszystkich przebadanych relacji z tych miast, ok. 70\% spełniało przyjęte kryteria dostępności dziennej. Warto podkreślić, iż podczas pomiaru dostępności dziennej transportem indywidualnym wystąpiły relacje, które w żadnym z przeanalizowanych wariantów godzinowych nie spełniły przyjętych kryteriów dostępności. Mianowicie podróż samochodem w relacjach Rzeszów-Gdańsk oraz Rzeszów-Szczecin okazała się trwać dłużej niż 8 godzin. Ostatecznie, różnica pomiędzy najlepiej a najsłabiej dostępnym miastem wyniosła 28 relacji, co w ujęciu procentowym stanowi 31,1\%.

Przeprowadzone badania potwierdzają, że wysokość wskaźnika dostępności dziennej transportem indywidualnym dla poszczególnych miast wojewódzkich jest zależna w głównej mierze od ich lokalizacji oraz rozkładu przestrzennego dróg szybkiego ruchu. Niższy poziom wskaźnika wśród miast zlokalizowanych peryferyjnie jest kwestią oczywistą, co stanowi pochodną odległości, jakie należy pokonać podróżując z jednego miasta do drugiego. W przypadku czterogodzinnego pobytu w miejscu docelowym łączna liczba połączeń w skali kraju, które spełniły przyjęte kryteria wyniosła 236 na 240, natomiast w wariantach zakładających dłuższy pobyt, różnice w poziomie dostępności dziennej okazały się stosunkowo wyraźne, w wyniku czego w przypadku wariantu sześciogodzinnego - 218 połączeń 
Tabela 1. Dostępność dzienna w układzie miast wojewódzkich w Polsce - transport indywidualny* Daily accessibility among pairs of voivodeship cities in Poland - individual transport

\begin{tabular}{|c|c|c|c|c|c|c|c|c|c|c|c|c|c|c|c|c|}
\hline $\begin{array}{l}\begin{array}{r}\text { Punkt } \\
\text { docelowy }\end{array} \\
\text { Punkt } \\
\text { początkowy }\end{array}$ & $\begin{array}{l}\frac{v}{0} \\
\frac{\tilde{N}}{\frac{1}{0}} \\
\frac{.0}{0}\end{array}$ & 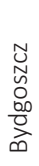 & 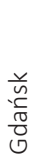 & 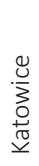 & $\frac{\stackrel{U}{U}}{\frac{\mathscr{U}}{\underline{v}}}$ & $\begin{array}{l}\frac{3}{0} \\
\frac{0}{\frac{0}{0}} \\
\frac{2}{2}\end{array}$ & $\frac{\stackrel{5}{0}}{\frac{0}{3}}$ & $\begin{array}{l}\text { N } \\
\text { D } \\
+\end{array}$ & 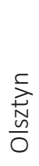 & $\begin{array}{l}\frac{\mathscr{U}}{0} \\
\frac{0}{0}\end{array}$ & $\begin{array}{l}\frac{1}{N} \\
\frac{\pi}{N} \\
0 \\
0\end{array}$ & $\begin{array}{l}3 \\
\stackrel{N}{N} \\
\stackrel{N}{N} \\
\simeq\end{array}$ & $\begin{array}{l}\cdot \bar{J} \\
\mathbb{N} \\
\text { N }\end{array}$ & 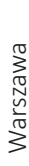 & $\begin{array}{l}3 \\
\frac{3}{ \pm} \\
\frac{0}{1} \\
3\end{array}$ & $\begin{array}{l}\frac{1}{2} \\
\frac{10}{0} \\
\frac{0}{0} \\
\frac{0}{0} \\
\frac{0}{2}\end{array}$ \\
\hline Białystok & $x$ & 3 & 2 & 2 & 3 & 2 & 3 & 3 & 3 & 2 & 3 & 2 & 1 & 3 & 2 & 2 \\
\hline Bydgoszcz & 3 & $x$ & 3 & 3 & 3 & 2 & 3 & 3 & 3 & 3 & 3 & 1 & 3 & 3 & 3 & 3 \\
\hline Gdańsk & 2 & 3 & $X$ & 2 & 2 & 2 & 2 & 3 & 3 & 2 & 3 & 0 & 3 & 3 & 2 & 3 \\
\hline Katowice & 2 & 3 & 2 & $x$ & 3 & 3 & 3 & 3 & 2 & 3 & 3 & 3 & 2 & 3 & 3 & 3 \\
\hline Kielce & 3 & 3 & 2 & 3 & $x$ & 3 & 3 & 3 & 3 & 3 & 3 & 3 & 1 & 3 & 3 & 2 \\
\hline Kraków & 2 & 2 & 2 & 3 & 3 & $x$ & 3 & 3 & 1 & 3 & 3 & 3 & 1 & 3 & 3 & 3 \\
\hline Lublin & 3 & 3 & 2 & 3 & 3 & 3 & $X$ & 3 & 3 & 2 & 3 & 3 & 1 & 3 & 2 & 2 \\
\hline Łódź & 3 & 3 & 3 & 3 & 3 & 3 & 3 & $x$ & 3 & 3 & 3 & 3 & 3 & 3 & 3 & 3 \\
\hline Olsztyn & 3 & 3 & 3 & 2 & 3 & 1 & 3 & 3 & $x$ & 1 & 3 & 1 & 1 & 3 & 2 & 2 \\
\hline Opole & 2 & 3 & 2 & 3 & 3 & 3 & 2 & 3 & 1 & $x$ & 3 & 3 & 3 & 3 & 3 & 3 \\
\hline Poznań & 3 & 3 & 3 & 3 & 3 & 3 & 3 & 3 & 3 & 3 & $x$ & 2 & 3 & 3 & 3 & 3 \\
\hline Rzeszów & 2 & 1 & 0 & 3 & 3 & 3 & 3 & 3 & 1 & 3 & 2 & $x$ & 0 & 3 & 3 & 2 \\
\hline Szczecin & 1 & 3 & 3 & 2 & 1 & 1 & 1 & 3 & 1 & 3 & 3 & 0 & $x$ & 3 & 3 & 3 \\
\hline Warszawa & 3 & 3 & 3 & 3 & 3 & 3 & 3 & 3 & 3 & 3 & 3 & 3 & 3 & $x$ & 3 & 3 \\
\hline Wrocław & 2 & 3 & 2 & 3 & 3 & 3 & 2 & 3 & 2 & 3 & 3 & 3 & 3 & 3 & $x$ & 3 \\
\hline Zielona Góra & 2 & 3 & 3 & 3 & 2 & 3 & 2 & 3 & 2 & 3 & 3 & 2 & 3 & 3 & 3 & $x$ \\
\hline
\end{tabular}

*Liczby w macierzy oznaczają, ile relacji pomiędzy poszczególnymi miastami wojewódzkimi spełnia kryteria dostępności dziennej.

Opracowanie własne na podstawie bazy danych IGiPZ PAN.

Authors' own elaboration based on the IGIPZ PAN database.

spełniło przyjęte kryteria, a w przypadku wariantu ośmiogodzinnego - 170. Jak ukazuje to załączona mapa (ryc. 1), miasta wojewódzkie położone przy północnej i wschodniej granicy kraju odstają poziomem wskaźnika dostępności dziennej od miast zlokalizowanych centralnie. Wspomniana peryferyjność nie odgrywa tak dużej roli w przypadku miast położonych przy południowej granicy kraju (za wyjątkiem Rzeszowa). Stolice południowych województw odznaczają się względnie wysokim wskaźnikiem dostępności dziennej w transporcie indywidualnym, co jest w szczególności uwarunkowane przebiegiem przecinającej te regiony autostrady A4 w kierunku wschód-zachód oraz dróg ekspresowych S3, S5 i S7 w kierunku północ-południe. Dowodzi to, że dobrze rozwinięta infrastruktura drogowa może, w przypadku kraju wielkości Polski, zapewnić dostępność dzienną także ośrodkom peryferyjnym.

Wyniki badań dostępności dziennej transportem kolejowym przedstawiono w tabeli 2. Dane liczbowe zamieszczone w macierzy interpretuje się analogicznie jak w przypadku transportu indywidualnego, a mianowicie im wyższy wynik na danej relacji, tym korzystniejsza sytuacja. Należy w tym miejscu przypomnieć, że dostępność dzienną w transporcie kolejowym badano w dwóch kierunkach. Uzyskane z rozkładów jazdy czasy przejazdu na jed- 


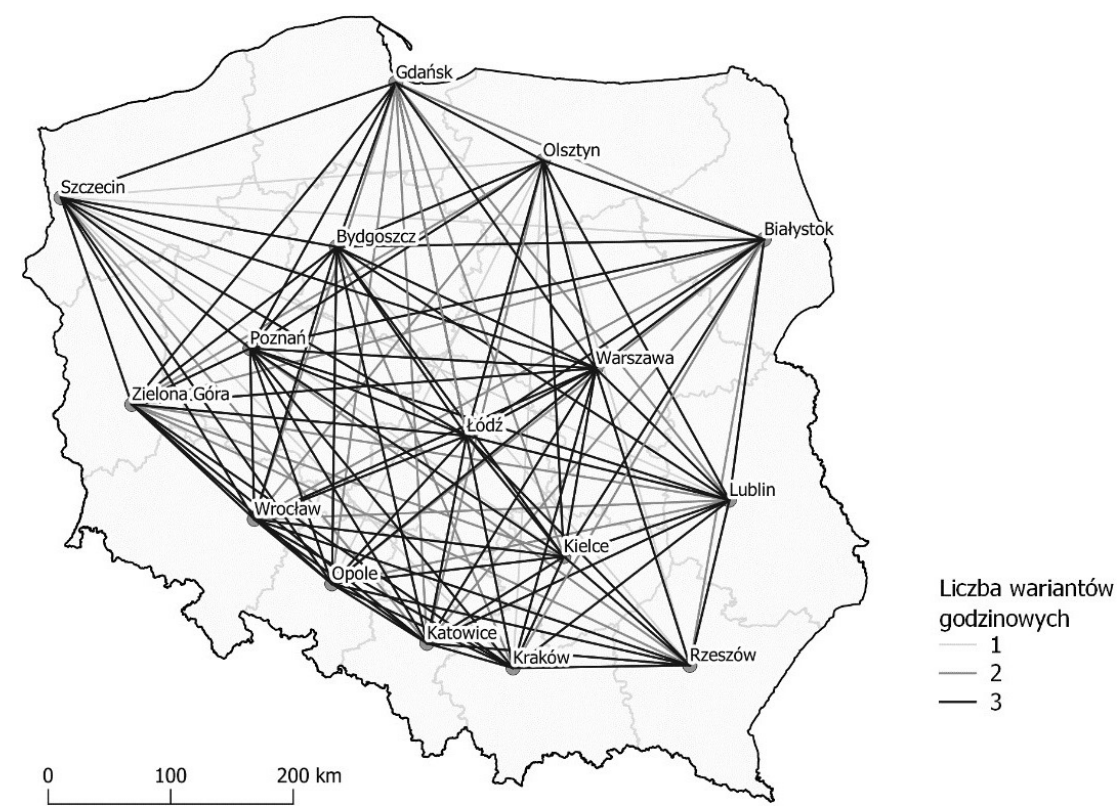

Ryc. 1. Zróżnicowanie przestrzenne wskaźnika dostępności dziennej transportem indywidualnym w układzie miast wojewódzkich w Polsce

Spatial diversity characterising the daily accessibility indicator for individual transport among voivodeship cities in Poland

Opracowanie własne na podstawie bazy danych IGiPZ PAN.

Authors' own elaboration based on the IGIPZ PAN database.

nej trasie, ale w przeciwnych kierunkach, mogły znacznie różnić się od siebie, co w rezultacie skutkowało różnicami w występowaniu dostępności w zależności od kierunku podróży.

Najlepiej skomunikowanym miastem wojewódzkim, jeżeli chodzi o ten rodzaj transportu, jest Warszawa. Sumując wyniki z trzech przebadanych wariantów godzinowych, w obu kierunkach, na 90 przebadanych relacji, 73 spełniało kryteria dostępności dziennej. Jest to ciekawa sytuacja, gdyż Warszawa leży w regionie cechującym się jednym z niższych wskaźników gęstości sieci kolejowej w Polsce, a jednocześnie jest miastem z najlepszą dostępnością. Widać wyraźnie, że istotny wpływ na wysokość wskaźnika ma w tym przypadku węzłowy charakter układu magistralnych linii kolejowych, łączących Warszawę z innymi częściami kraju. Korzystna sytuacja Warszawy świadczy także o dużym popycie na przewozy pasażerskie w relacjach z pozostałymi miastami wojewódzkimi. Mimo to istnieją trzy ośrodki, które w połączeniach do i z Warszawy cechuje mocno ograniczony poziom dostępności dziennej lub zupełny jej brak (Rzeszów, Szczecin, Zielona Góra), przy czym gorsza sytuacja dotyczy kierunku, w którym punktem początkowym podróży jest stolica. Trzy wymienione miasta znajdują się w znacznym oddaleniu od Warszawy, co wiąże się z odpowiednio dłuższym czasem podróży. Dodatkowo do wydłużenia czasu przyczyniają się czynniki takie jak: niezadowalający stan infrastruktury na niektórych odcinkach, gdzie prace modernizacyjne nie zostały jeszcze ukończone (Poznań - Szczecin, Lublin - Rzeszów), bądź niekorzystny kształt sieci kolejowej, wymuszający trasy dalekie od przebiegu prostoliniowego (połączenie Rzeszowa przez Kraków oraz Zielonej Góry przez Poznań). 
Tabela 2. Dostępność dzienna w układzie miast wojewódzkich w Polsce - transport kolejowy* Daily accessibility among pairs of voivodeship cities in Poland - railway transport

\begin{tabular}{|c|c|c|c|c|c|c|c|c|c|c|c|c|c|c|c|c|}
\hline $\begin{array}{l}\begin{array}{l}\text { Punkt } \\
\text { docelowy }\end{array} \\
\text { Punkt } \\
\text { początkowy }\end{array}$ & 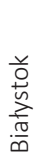 & $\begin{array}{l}\tilde{N} \\
\text { O } \\
\text { Do } \\
\text { Oे }\end{array}$ & $\begin{array}{l}\frac{.}{n} \\
\frac{\pi}{\pi} \\
\frac{\pi}{0}\end{array}$ & 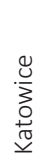 & $\frac{\stackrel{U}{U}}{\frac{Q}{2}}$ & $\begin{array}{l}\frac{3}{0} \\
\frac{0}{\frac{0}{0}} \\
\frac{1}{2}\end{array}$ & $\frac{. 气}{\frac{亏}{3}}$ & $\begin{array}{l}\mathbb{N} \\
\stackrel{D}{+}\end{array}$ & 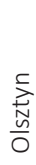 & $\begin{array}{l}\frac{0}{\circ} \\
\text { on }\end{array}$ & 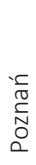 & 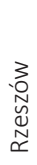 & $\begin{array}{l}\bar{\Xi} \\
\mathbb{N} \\
N \\
N\end{array}$ & 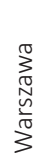 & $\begin{array}{l}3 \\
\frac{3}{4} \\
\text { L } \\
3\end{array}$ & $\begin{array}{l}\frac{0}{0} \\
0 \\
0 \\
0 \\
\frac{0}{0} \\
\frac{0}{2}\end{array}$ \\
\hline Białystok & $x$ & 0 & 2 & 1 & 1 & 2 & 1 & 3 & 3 & 0 & 0 & 0 & 0 & 3 & 0 & 0 \\
\hline Bydgoszcz & 0 & $x$ & 3 & 0 & 0 & 0 & 0 & 2 & 3 & 1 & 3 & 0 & 1 & 3 & 2 & 3 \\
\hline Gdańsk & 0 & 3 & X & 1 & 1 & 1 & 0 & 1 & 3 & 0 & 3 & 0 & 2 & 2 & 1 & 0 \\
\hline Katowice & 0 & 0 & 1 & $x$ & 3 & 3 & 0 & 3 & 0 & 3 & 2 & 2 & 0 & 3 & 3 & 1 \\
\hline Kielce & 0 & 0 & 0 & 3 & $x$ & 3 & 2 & 2 & 0 & 2 & 0 & 1 & 0 & 3 & 2 & 0 \\
\hline Kraków & 0 & 0 & 1 & 3 & 3 & $x$ & 2 & 3 & 0 & 3 & 2 & 3 & 0 & 3 & 3 & 0 \\
\hline Lublin & 0 & 0 & 0 & 0 & 3 & 2 & $x$ & 1 & 0 & 0 & 0 & 2 & 0 & 3 & 0 & 0 \\
\hline tódź & 2 & 2 & 2 & 3 & 2 & 3 & 1 & $x$ & 2 & 3 & 3 & 1 & 1 & 3 & 3 & 1 \\
\hline Olsztyn & 1 & 3 & 3 & 1 & 1 & 1 & 0 & 2 & $x$ & 0 & 2 & 0 & 0 & 3 & 0 & 0 \\
\hline Opole & 0 & 1 & 0 & 3 & 3 & 3 & 0 & 3 & 0 & $x$ & 3 & 1 & 0 & 3 & 3 & 2 \\
\hline Poznań & 0 & 3 & 3 & 2 & 0 & 1 & 0 & 2 & 2 & 3 & $x$ & 0 & 3 & 3 & 3 & 3 \\
\hline Rzeszów & 0 & 0 & 0 & 2 & 1 & 3 & 2 & 1 & 0 & 1 & 0 & $x$ & 0 & 2 & 0 & 0 \\
\hline Szczecin & 0 & 1 & 2 & 0 & 0 & 0 & 0 & 1 & 0 & 0 & 3 & 0 & $x$ & 0 & 1 & 3 \\
\hline Warszawa & 3 & 3 & 3 & 3 & 2 & 3 & 3 & 3 & 3 & 3 & 3 & 1 & 0 & $x$ & 2 & 0 \\
\hline Wrocław & 0 & 3 & 1 & 3 & 3 & 3 & 0 & 3 & 0 & 3 & 3 & 1 & 1 & 3 & $x$ & 3 \\
\hline Zielona Góra & 0 & 2 & 0 & 2 & 0 & 1 & 0 & 1 & 0 & 3 & 3 & 0 & 1 & 1 & 3 & $x$ \\
\hline
\end{tabular}

*Liczby w macierzy oznaczają, ile relacji pomiędzy poszczególnymi miastami wojewódzkimi spełnia kryteria dostępności dziennej.

Opracowanie własne na podstawie bazy danych rozkładów jazdy kolei obowiązujących w październiku 2017 r. Authors' own elaboration based on the railway timetables database in force in October 2017.

Podobnie jak w przypadku transportu indywidualnego drugim najlepiej skomunikowanym miastem wojewódzkim okazała się położona w centralnej części kraju Łódź, w przypadku której 70\% analizowanych połączeń spełniło przyjęte kryteria. Na następnych miejscach znalazł się Poznań oraz miasta wojewódzkie zlokalizowane w regionach o najwyższej gęstości sieci kolejowej, czyli Wrocław, Kraków, Katowice i Opole. Najgorzej wypadł Szczecin, ponieważ zaledwie 20 relacji (czyli 22\%) z wszystkich przebadanych spełniało kryteria dostępności dziennej. Należy domniemywać, że w tej sytuacji tak słaby wynik spowodowany był peryferyjnym położeniem Szczecina oraz niższą jakością infrastruktury torowej łączącej go z Wrocławiem, Poznaniem i Gdańskiem. W przypadku transportu kolejowego różnica pomiędzy najlepiej a najsłabiej dostępnym miastem wyniosła 53 punkty, co w ujęciu procentowym stanowi ok. 59\%. Taka sytuacja z pewnością oznacza silną polaryzację potrzeb inwestycyjnych w kwestii rozwoju infrastruktury kolejowej.

W układzie przestrzennym (ryc. 2) relacji kolejowych między miastami wojewódzkimi, wykazujących dostępność dzienną, można zauważyć wyraźnie mniejszą ogólną liczbę połączeń, aniżeli obserwowana w transporcie indywidualnym. W wariancie czterogodzinnym liczba połączeń, które spełniły kryteria dostępności dziennej, wyniosła 152, 


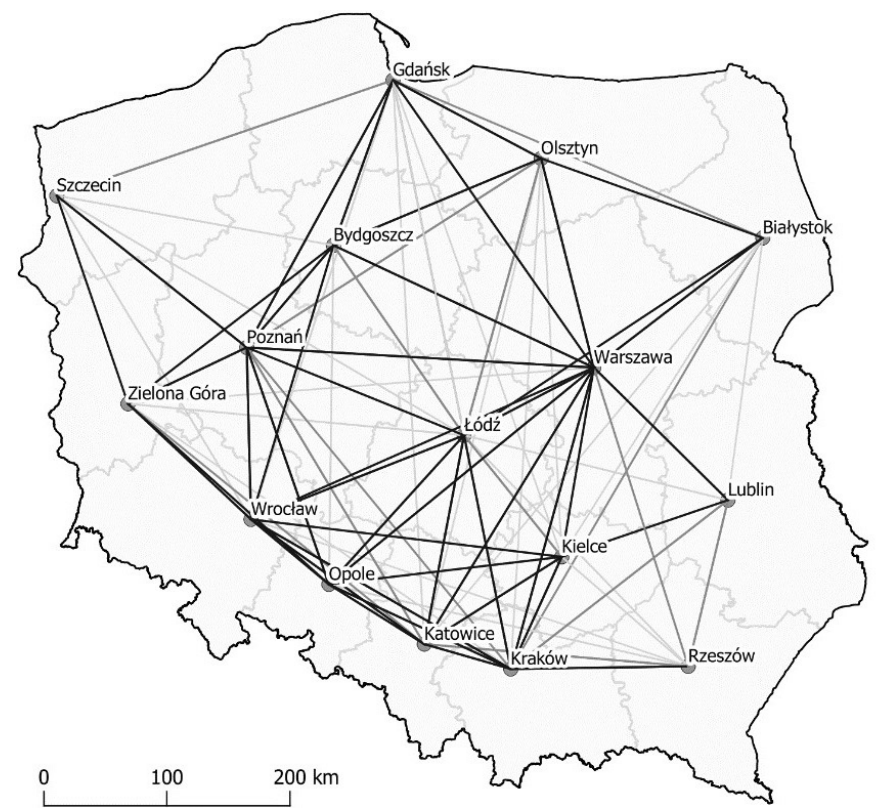

Liczba wariantów godzinowych

1

$-2$

$-3$

Ryc. 2. Zróżnicowanie przestrzenne wskaźnika dostępności dziennej transportem kolejowym w układzie miast wojewódzkich w Polsce Spatial diversity of characterising the daily accessibility indicator in for railway transport between among voivodeship cities in Poland

Opracowanie własne na podstawie bazy danych rozkładów jazdy kolei obowiązujących w październiku 2017 r. Authors' own elaboration based on the railway timetables database applying in October 2017.

w wariancie sześciogodzinnym ich liczba spadła do 112, natomiast w wariancie ośmiogodzinnym wyniosła 77 połączeń na 240 możliwych. Dominują relacje „do najbliższego sąsiada”. Znacznie mniej jest sytuacji występowania dostępności dziennej, gdy ośrodki są od siebie bardziej oddalone, przy czym rzadko wskaźnik osiąga w takim przypadkach wartość 2 lub 3. Dotyczy to miast posiadających najszybsze połączenia o najwyższej kategorii (Ekspres Intercity Premium oraz Ekspres Intercity), np. Warszawa-Kraków, Warszawa-Poznań, Warszawa-Gdańsk, Warszawa-Wrocław.

Odniesienie uzyskanych wyników do gęstości oraz stanu technicznego sieci kolejowej (maksymalnych dopuszczalnych prędkości) w poszczególnych województwach, wskazuje na istotny związek pomiędzy wartością wskaźnika dostępności dziennej danego miasta wojewódzkiego, a wyposażeniem w infrastrukturę kolejową regionu, którego jest stolicą. Warto jednak pamiętać, że na obniżenie poziomu dostępności dziennej mogą także wpływać tymczasowo prace modernizacyjne, co w pewnym stopniu mogło przyczynić się do słabszego wyniku niektórych miast.

\section{Ujęcie syntetyczne dostępności dziennej w układzie miast wojewódzkich w Polsce}

Zestawienie ze sobą wartości wskaźników dostępności dziennej, uzyskanych w wyniku analiz dla poszczególnych relacji w transporcie indywidualnym i kolejowym, umożliwiło 
obliczenie sumarycznego wskaźnika dostępności dziennej w przypadku każdego z badanych miast wojewódzkich. W dalszej kolejności pozwoliło to na utworzenie rankingu miast, odzwierciedlającego między innymi ich potencjał do kształtowania wzajemnych powiązań funkcjonalno-przestrzennych (tab. 3). Załączony ranking daje także możliwość określenia, które stolice województw wypadają najlepiej pod kątem podróży jednodniowych i który typ transportu odgrywa wiodąca rolę w tworzeniu powiązań z danym miastem. Analiza dostępności dziennej na podstawie czasów przejazdu zobrazowała ponadto poziom spójności przestrzennej wewnątrz sieci polskich metropolii. Możliwa jest dzięki temu identyfikacja obszarów wymagających dodatkowych działań inwestycyjnych lub zmian w sferze organizacyjnej transportu, które potencjalnie mogłyby przyczynić się do umocnienia spójności międzyregionalnej.

Miastem wojewódzkim o najwyższym sumarycznym wskaźniku dostępności dziennej jest Warszawa. Na 180 przebadanych relacji między Warszawą a pozostałymi miastami wojewódzkimi 163 (90,6\%) zmieściło się w wybranych przedziałach. Warszawa uzyskała najlepszy wynik zarówno jeżeli chodzi o transport indywidualny, jak i kolejowy. Z pewnością na wysoki poziom dostępności dziennej stolicy województwa mazowieckiego wpływa

Tabela 3. Ranking polskich miast wojewódzkich w zakresie poziomu dostępności dziennej Ranking of Poland's voivodeship cities by overall level of daily accessibility

\begin{tabular}{|c|c|c|c|c|c|c|c|}
\hline \multirow{3}{*}{$\begin{array}{c}\text { Pozycja } \\
\text { w rankingu }\end{array}$} & \multirow{3}{*}{ Miasto } & \multicolumn{4}{|c|}{ Wskaźnik dostępności dziennej } & \multirow{3}{*}{$\begin{array}{l}\text { Sumaryczny wskaźnik } \\
\text { dostępności dziennej }\end{array}$} & \multirow{3}{*}{$\% *$} \\
\hline & & \multicolumn{2}{|c|}{ transport indywidualny } & \multicolumn{2}{|c|}{ transport kolejowy } & & \\
\hline & & z miasta & do miasta & z miasta & do miasta & & \\
\hline 1 & Warszawa & 45 & 45 & 35 & 38 & 163 & 90,6 \\
\hline 2 & Łódź & 45 & 45 & 32 & 31 & 153 & 85,0 \\
\hline 3 & Poznań & 44 & 44 & 28 & 30 & 146 & 81,1 \\
\hline 4 & Wrocław & 41 & 41 & 30 & 26 & 138 & 76,7 \\
\hline 5 & Katowice & 41 & 41 & 24 & 27 & 133 & 73,9 \\
\hline 6 & Kraków & 38 & 38 & 26 & 29 & 131 & 72,8 \\
\hline 7 & Opole & 40 & 40 & 25 & 25 & 130 & 72,2 \\
\hline 8 & Bydgoszcz & 42 & 42 & 21 & 21 & 126 & 70,0 \\
\hline 9 & Kielce & 41 & 41 & 18 & 23 & 123 & 68,3 \\
\hline 10 & Zielona Góra & 40 & 40 & 17 & 16 & 113 & 62,8 \\
\hline 11 & Gdańsk & 35 & 35 & 18 & 21 & 109 & 60,6 \\
\hline 12 & Olsztyn & 34 & 34 & 17 & 16 & 101 & 56,1 \\
\hline 13 & Lublin & 39 & 39 & 11 & 11 & 100 & 55,6 \\
\hline 14 & Białystok & 36 & 36 & 16 & 6 & 94 & 52,2 \\
\hline 15 & Rzeszów & 32 & 32 & 12 & 12 & 88 & 48,9 \\
\hline 16 & Szczecin & 31 & 31 & 11 & 9 & 82 & 45,6 \\
\hline
\end{tabular}

*Wartość \% sumarycznego wskaźnika dostępności dziennej, gdzie 100\% = 180 (maksymalna możliwa wartość) Opracowanie własne na podstawie rozkładu jazdy pociągów obowiązującego w październiku 2017 r. oraz bazy danych czasów przejazdu transportem indywidualnym IGiPZ PAN.

Authors' own elaboration based on the railway timetables database applying in October 2017, as well as the IGIPZ PAN database of travel times in individual transport. 
także jej funkcja - stolicy kraju. W związku z tym popyt na przejazdy w relacjach Warszawa - inne części kraju jest znacznie wyższy w stosunku do przejazdów w innych relacjach. Przekłada się to między innymi na większą podaż połączeń kolejowych oraz na konieczność skomunikowania Warszawy z innymi regionami za pomocą dróg szybkiego ruchu. Na poziom popytu wpływa także lokalizacja centrów biznesowych oraz duża liczba osób dojeżdżających do pracy. Dzięki wysokiemu poziomowi dostępności Warszawa pełni także funkcję krajowego węzła transportowego, umożliwiającego podróż do pozostałych części Polski, Europy i świata. Zdecydowanie wyższą dostępnością dzienną na tle kraju cechują się także dwa inne miasta zlokalizowane mniej lub bardziej centralnie - Łódź oraz Poznań. Wszystkie trzy z wymienionych ośrodków, pod względem wielkości wskaźnika sumarycznego, przeważają nad stolicami województw graniczących z sąsiednimi państwami. Należy w tym miejscu zwrócić uwagę na mniejsze dysproporcje pomiędzy transportem indywidualnym a kolejowym w miastach o ogólnie wyższym poziomie dostępności. Zaistniała sytuacja jest wynikiem lepiej rozwiniętej infrastruktury transportowej w tych regionach kraju. W pewnym sensie stawia to mieszkańców w korzystniejszym położeniu, ponieważ chcąc realizować podróże jednodniowe, nie są oni w takim stopniu zależni od jednego środka transportu, jak mieszkańcy regionów o słabszym wyposażeniu w infrastrukturę transportową.

Badania wykazały także, że wschodnia część kraju cechuje się słabszą dostępnością dla obu analizowanych typów transportu. Białystok, Lublin oraz Rzeszów w ostatecznym rankingu wypadły znacznie słabiej od pozostałych miast wojewódzkich zarówno jeżeli chodzi o transport indywidualny, jak i kolejowy. Porównując obie gałęzie transportu można zauważyć, że w województwach wschodnich dominuje transport indywidualny. Zaistniała sytuacja powoduje, iż mieszkańcy Białegostoku, Lublina oraz Rzeszowa, chcąc realizować podróże jednodniowe do innych ośrodków wojewódzkich, są w znacznie większym stopniu uzależnieni od posiadania własnego samochodu bądź korzystania z transportu autobusowego, co często wiąże się z dodatkowymi niedogodnościami. Wspomniane niedogodności wynikają między innymi z wydłużonego czasu podróży spowodowanego koniecznością przesiadki, czasem oczekiwania wynikającym z niedostosowanych rozkładów jazdy, nierzadko też koniecznością zmiany przystanku bądź tym, że dany przewoźnik obsługuje większą liczbę przystanków, przez co podróż znacznie się wydłuża. Niedogodności wynikające z podwyższonych kosztów w przypadku transportu autobusowego mogą być spowodowane np. koniecznością zakupu oddzielnego biletu. Natomiast jeżeli chodzi o koszty związane z posiadaniem własnego środka transportu, wskazać można m.in. koszt uzyskania prawa jazdy, zakupu środka transportu oraz koszty związane z jego utrzymaniem i eksploatacją. Rezultaty badań odzwierciedlają w pewnym sensie poziom rozwoju, na którym znajduje się region Polski Wschodniej oraz wskazują na potrzeby inwestycyjne, które są nieco wyższe w tym regionie w porównaniu z pozostałą częścią kraju.

Różnica pomiędzy najlepiej a najsłabiej skomunikowanym miastem pod względem sumarycznego wskaźnika dostępności dziennej wyniosła 81 punktów, czyli 45\%. W przypadku kolei różnica była znacznie wyższa niż w transporcie indywidualnym, co wynika w szczególności ze znacznego niedoinwestowania infrastruktury kolejowej w regionach peryferyjnych. W związku z tym więcej par miast wojewódzkich posiadało relacje spełniające kryteria dostępności dziennej dla transportu samochodowego.

Łączna macierz połączeń (tab. 4) wskazuje, które miasta mają szanse na tworzenie powiązań funkcjonalno-przestrzennych, które mogą przynosić korzyści np. ekonomiczne 
Tabela 4. Dostępność dzienna w układzie miast wojewódzkich w Polsce - transport kolejowy i indywidualny łącznie*

Daily accessibility among pairs of voivodeship cities in Poland - combined rail and individual transport

\begin{tabular}{|c|c|c|c|c|c|c|c|c|c|c|c|c|c|c|c|c|}
\hline $\begin{array}{l}\begin{array}{r}\text { Punkt } \\
\text { docelowy }\end{array} \\
\text { Punkt } \\
\text { początkowy }\end{array}$ & $\begin{array}{l}\frac{y}{0} \\
\frac{w}{n} \\
\frac{0}{0}\end{array}$ & 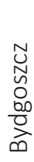 & 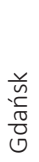 & 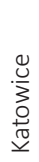 & $\frac{d}{\frac{U}{v}}$ & $\begin{array}{l}30 \\
\frac{3}{20} \\
\frac{10}{20}\end{array}$ & 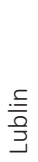 & 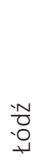 & $\frac{\underset{N}{N}}{\stackrel{N}{N}}$ & $\begin{array}{l}\frac{0}{0} \\
\frac{0}{0}\end{array}$ & 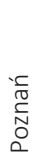 & 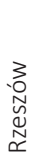 & $\begin{array}{l}\cdot \frac{5}{U} \\
\mathbb{N} \\
N \\
N\end{array}$ & 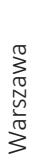 & 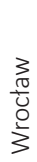 & $\begin{array}{l}\frac{0}{0} \\
\frac{0}{10} \\
\frac{0}{c} \\
\frac{0}{2} \\
\frac{1}{N}\end{array}$ \\
\hline Białystok & $x$ & 3 & 4 & 3 & 4 & 4 & 4 & 6 & 6 & 2 & 3 & 2 & 1 & 6 & 2 & 2 \\
\hline Bydgoszcz & 3 & $x$ & 6 & 3 & 3 & 2 & 3 & 5 & 6 & 4 & 6 & 1 & 4 & 6 & 5 & 6 \\
\hline Gdańsk & 2 & 6 & $x$ & 3 & 3 & 6 & 2 & 4 & 6 & 2 & 6 & 0 & 5 & 8 & 3 & 3 \\
\hline Katowice & 2 & 3 & 3 & $x$ & 6 & 6 & 3 & 6 & 2 & 6 & 5 & 5 & 2 & 9 & 6 & 4 \\
\hline Kielce & 3 & 3 & 2 & 6 & $x$ & 6 & 5 & 5 & 3 & 5 & 3 & 4 & 1 & 6 & 5 & 2 \\
\hline Kraków & 2 & 2 & 6 & 6 & 6 & $x$ & 5 & 6 & 1 & 6 & 5 & 6 & 1 & 9 & 6 & 3 \\
\hline Lublin & 3 & 3 & 2 & 3 & 6 & 5 & $x$ & 4 & 3 & 2 & 3 & 5 & 1 & 6 & 2 & 2 \\
\hline Łódź & 5 & 5 & 5 & 6 & 5 & 6 & 4 & $x$ & 5 & 6 & 6 & 4 & 4 & 6 & 6 & 4 \\
\hline Olsztyn & 4 & 6 & 6 & 3 & 4 & 2 & 3 & 5 & $x$ & 1 & 5 & 1 & 1 & 6 & 2 & 2 \\
\hline Opole & 2 & 4 & 2 & 6 & 6 & 6 & 2 & 6 & 1 & $x$ & 6 & 4 & 3 & 6 & 6 & 5 \\
\hline Poznań & 3 & 6 & 6 & 5 & 3 & 4 & 3 & 5 & 5 & 6 & $x$ & 2 & 6 & 9 & 6 & 6 \\
\hline Rzeszów & 2 & 1 & 0 & 5 & 4 & 6 & 5 & 4 & 1 & 4 & 2 & $x$ & 0 & 8 & 3 & 2 \\
\hline Szczecin & 1 & 4 & 5 & 2 & 1 & 1 & 1 & 4 & 1 & 3 & 6 & 0 & $x$ & 6 & 4 & 6 \\
\hline Warszawa & 6 & 6 & 9 & 7 & 5 & 9 & 6 & 6 & 6 & 6 & 9 & 6 & 6 & $x$ & 8 & 3 \\
\hline Wrocław & 2 & 6 & 3 & 6 & 6 & 6 & 2 & 6 & 2 & 6 & 6 & 4 & 4 & 9 & $x$ & 6 \\
\hline Zielona Góra & 2 & 5 & 3 & 5 & 2 & 4 & 2 & 4 & 2 & 6 & 6 & 2 & 4 & 4 & 6 & $x$ \\
\hline
\end{tabular}

*Liczby w macierzy oznaczają, ile relacji pomiędzy poszczególnymi miastami wojewódzkimi spełnia kryteria dostępności dziennej.

Opracowanie własne na podstawie bazy danych rozkładów jazdy kolei obowiązujących w październiku 2017 r. oraz bazy danych IGiPZ PAN.

Authors' own elaboration based on the railway timetable database applying in October 2017 and the IGiPZ PAN database.

i społeczne. Powiązania te generują znaczący potencjał rozwojowy i umacniają policentryczność układu osadniczego.

Tym samym wskaźnik dostępności dziennej jest istotny nie tylko ze względu na to, iż odpowiada na pytanie: pomiędzy którymi miastami wojewódzkimi jakość transportu jest dobra? Przede wszystkim wskazuje, które regiony są ze sobą powiązane lub mogą te powiązania tworzyć, by stymulować własny rozwój. Według R. Domańskiego (2005), wzajemna wymiana wiedzy i kreatywności pomiędzy metropoliami (aglomeracjami), prowadząca do efektów synergii, wymaga powiązania ośrodków efektywnym systemem transportowym.

Analizując układ przestrzenny oraz stan techniczny infrastruktury drogowej i kolejowej w Polsce można domniemywać, w jakim stopniu dodatkowe inwestycje mogłyby przyczynić się do poprawy dostępności dziennej miast wojewódzkich. Wydaje się, że polska infrastruktura drogowa jest na takim etapie rozwoju, na którym dodatkowe inwestycje nie przełożą się w odczuwalnym stopniu na poprawę dostępności dziennej (za wyjątkiem 
regionu Polski Wschodniej). Natomiast w przypadku transportu kolejowego istnieje wciąż duży zakres relacji wymagających poprawy. Może to być osiągnięte częściowo poprzez optymalizację rozkładu jazdy. Niestety nie zawsze pozwoli na to dostępna infrastruktura, a plany inwestycyjne nie wszędzie będą mogły sprostać realnym potrzebom.

\section{Podsumowanie}

Przeprowadzone badania wykazały, że najlepszą dostępność dzienną do innych miast wojewódzkich w Polsce posiada Warszawa, a zdecydowanie wysoką dostępnością cechują się także inne miasta zlokalizowane centralnie. Ośrodki wojewódzkie Polski Wschodniej wypadły znacznie słabiej na tle kraju zarówno w przypadku transportu indywidualnego, jak i kolejowego. Analizy pozwoliły także na stwierdzenie, że więcej par miast wojewódzkich cechuje dostępność dzienna transportem indywidualnym niż kolejowym. Ponadto w przypadku kolei występuje większa polaryzacja w zakresie poziomu dostępności dziennej. Nieproporcjonalnie wyższy jest poziom sumarycznego wskaźnika dostępności dziennej Warszawy w stosunku do pozostałych miast wojewódzkich.

Rozpatrując uzyskane wyniki w kontekście potencjalnych powiązań sieciowych wyraźnie uwidoczniła się peryferyzacja Szczecina i Rzeszowa. Mniejsze dysproporcje pomiędzy transportem indywidualnym a kolejowym wystąpiły w miastach cechujących się wyższym wskaźnikiem dostępności dziennej. Natomiast wyraźna przewaga transportu indywidualnego nad kolejowym dotyczyła Białegostoku, Lublina, Rzeszowa i Szczecina.

W nawiązaniu do celu pracy, rozwój obecnego układu dróg i linii kolejowych mógłby stworzyć bardzo korzystne warunki do kształtowania się policentrycznej metropolii sieciowej, o której mówi Koncepcja Przestrzennego Zagospodarowania Kraju 2030 (2011). Zgodnie z wyznacznikami policentryczności przyjętymi w projekcie ESPON 1.1.1. Potentials for polycentric development in Europe (2005), Polska spełnia dwa z trzech kryteriów, jakimi są: wielkość ośrodków i ich pozycja w krajowym systemie osadniczym oraz lokalizacja, rozumiana jako w miarę równomierny rozkład przestrzenny wspomnianych ośrodków. Kryterium, którego Polska nie spełnia, stanowią powiązania wzajemne. Układ powiązań jest w większym stopniu monocentryczny (ukierunkowany na stolicę) niż sieciowy (Komornicki i inni, 2013).

Warunkiem wzmocnienia tak rozumianego policentrycznego systemu polskich miast jest tym samym konsekwentna rozbudowa systemów transportowych pozwalająca na zwiększanie liczby relacji, na których mówić możemy o istnieniu dostępności dziennej. Przeprowadzona analiza potwierdza pośrednio, że dotychczasowe działania w tym zakresie poprawiły pozycję Warszawy, a w drugiej kolejności Łodzi i Poznania. Jest to zbieżne z wynikami innych analiz dostępności (Komornicki i inni, 2018) dowodzącymi, że w wyniku szeroko zakrojonych inwestycji Polska stała się bardziej spolaryzowana. Jest to zjawisko naturalne. Brak różnic u progu akcesji był wynikiem złego stanu infrastruktury w całym kraju. Modernizowanie niektórych szlaków zawsze prowadzi do polaryzacji. Jeżeli proces inwestycyjny w Polsce zostałby obecnie zatrzymany (np. na skutek braku dostępu do środków Unii Europejskiej w kolejnej perspektywie finansowej po roku 2020), to kraj pozostałby z infrastrukturą transportową zapewniającą ogólnie dobrą dostępność, ale jednocześnie wspierającą polaryzację społeczno-gospodarczą. W kontekście dostępności dziennej oznacza to utrzymanie układu policentrycznego na poziomie najważniejszych metropolii, 
ale jego osłabienie na szczeblu mniejszych i bardziej peryferyjnych miast wojewódzkich. Oznacza to, że tworzenie metropolii sieciowej jest procesem etapowym. Od podjętego wysiłku inwestycyjnego i organizacyjnego, zapewaniającego wzrost liczby par miast wzajemnie dobrze dostępnych, zależy, czy możliwy będzie kolejny etap faktycznego usieciowienia polskiego układu osadniczego.

Wysoki poziom sumarycznego wskaźnika dostępności dziennej miast Polski centralnej oraz południowej świadczy w pewnym sensie o spójności przestrzennej, co pozwala na tworzenie różnego rodzaju powiązań funkcjonalnych. W przypadku miast wojewódzkich zlokalizowanych peryferyjnie KPZK 2030 przewiduje działania aktywizujące i kompensujące ograniczoną możliwość wykorzystania ich potencjałów rozwojowych. Do działań tych z pewnością powinna zaliczać się poprawa poziomu dostępności transportowej w relacjach między największymi ośrodkami.

\section{Piśmiennictwo}

Arranz-Lopez A., Soria-Lara J.A., Pueyo-Campos A., 2019, Social and spatial equity effects of non-motorised accessibility to retail, Cities, 86, s. 71-82.

Batten D.F., 1995, Network Cities: Creative Urban Agglomerations for the 21st Century, Urban Studies, 32, 2, s. 313-327.

Chądzyńska E., 2014, Powiq̨zania funkcjonalne dużego miasta i aglomeracji z otoczeniem regionalnym w kontekście dostępności przestrzennej (przykład Szczecina), Studia Miejskie, 14, s. 27-42.

Cowell M., 2010, Polycentric Regions: Comparing Complementarity and Institutional Governance in the San Francisco Bay Area, The Randstad and Emilia Romagna, Urban Studies, 47, 5, s. 945-965.

Domański R., 2005, Geografia ekonomiczna. Ujęcie dynamiczne, Wydawnictwo Naukowe PWN, Warszawa.

Domański R., Marciniak A., 2003, Sieciowe koncepcje miast i regionów, Studia KPZK PAN, 113, Wydawnictwo Naukowe PWN, Warszawa.

ESPON 1.2.1., 2004, Transport services and networks: territorial trends and basic supply of infrastructure for territorial cohesion, Final Report, www.espon.eu (08.11.2019).

ESPON 1.1.1., 2005, Potentials for polycentric development in Europe, Final Report, Revised version, www.espon.eu (08.11.2019).

ESPON SeGI, 2012, Services of General Interests, Final Report, www.espon.eu (08.11.2019).

ESPON TRACC, 2013, Transport Accessibility at Regional/Local Scale and Patterns in Europe, Final Report, Version 20/06/2013, Volume 3, TRACC Regional Case Study Book, Part C, Case Studies Bavaria, www.espon.eu (27.05.2020).

ESPON TRACC, 2013, TRansport ACCessibility at Regional/Local Scale and Patterns in Europe. Draft Final Report. ESPON Applied Research, www.espon.eu (27.05.2020).

ESPON TRACC, 2015, Transport Accessibility at Regional/Local Scale and Patterns in Europe, Final Report, Version 06/02/2015, Volume 4, TRACC Accessibility Indicator Factsheets, www.espon. eu (08.11.2019).

Falkowski M., Pytel M., 2014, Analiza geopolityczna aktualnego stanu sieci kolejowej w Polsce, Przegląd Geopolityczny, 9, s. 71-94.

GDDKiA, 2020, Mapa Stanu Budowy Dróg - Polska, Generalna Dyrekcja Dróg Krajowych i Autostrad, https://www.gddkia.gov.pl/pl/1077/mapa-stanu-budowy-drog (28.05.2020). 
Geurs K.T., van Eck R., 2001, Accessibility Measures: Review and Applications, RIVM Report 408505006 , National Institute of Public Health and the Environment, Bilthoven.

Geurs K.T., van Wee B., 2004, Accessibility evaluation of land-use and transport strategies: review and research directions, Journal of Transport Geography 12, 2, s. 127-140.

GUS, 2011, Drogi ekspresowe i autostrady, Główny Urząd Statystyczny, Warszawa.

GUS, 2017, Drogi ekspresowe i autostrady, Główny Urząd Statystyczny, Warszawa.

Gutierrez J., 2001, Location, economic potential and daily accessibility: an analysis of the accessibility impact of the high-speed line Madrid-Barcelona-French border, Journal of Transport Geography, 9, s. 229-242.

Jiao J., Wang J., Jin F., 2017, Impacts of high-speed rail lines on the city network in China, Journal of Transport Geography, 60, s. 257-266.

Kelobonye K., McCarney G., Xia J., Swapan M.S.H., Mao F., Zhou H., 2019, Relative accessibility analysis for key land uses: A spatial equity perspective, Journal of Transport Geography, 75, s. 82-93.

Kloosterman R.C., Musterd S., 2001, The Polycentric Urban Region: Towards a Research Agenda, Urban Studies, 38, 4, s. 623-633.

Komornicki T., 2011, Dostępność transportowa Polski Zachodniej. Analiza uwzględniajqca europejska politykę TEN oraz korytarze o charakterze ponadregionalnym wiq̨żqce makroregion z terytorium europejskim i poprawiajqce dostępność transportowq wszystkich ośrodków powiatowych, IGiPZ PAN, Warszawa (ekspertyza).

Komornicki T., 2019, Transport infrastructure and accessibility, [w:] G. Gorzelak (red.), Social and economic development in Central and Eastern Europe: Stability and change after 1990, Routledge, London.

Komornicki T., Korcelli P., Siłka P., Śleszyński P., Świątek D., 2013, Powiqzzania funkcjonalne pomiędzy polskimi metropoliami, IGiPZ PAN, Warszawa, s. 45-59.

Komornicki T., Rosik P., Stępniak M., Śleszyński P., Goliszek P., Pomianowski W., Kowalczyk K., 2018, Ewaluacja i monitoring zmian dostępności transportowej w Polsce z wykorzystaniem wskaźnika WMDT, IGiPZ PAN, Ministerstwo Inwestycji i Rozwoju, Warszawa.

Komornicki T., Stępniak M., 2015, New investment projects in the road corridors and the improvement of the potential accessibility in Poland, Europa XXI, 28, IGiPZ PAN, Warszawa, s. 30-51.

Komornicki T., Śleszyński P., Rosik P., Pomianowski W., 2010, Dostępność przestrzenna jako przesłanka kształtowania polskiej polityki transportowej, Polska Akademia Nauk, Komitet Przestrzennego Zagospodarowania Kraju, Biuletyn, 241, Warszawa.

Koncepcja Przestrzennego Zagospodarowania Kraju 2030, 2011, Ministerstwo Rozwoju Regionalnego, Warszawa.

Korcelli P., Degórski M., Drzazga D., Komornicki T., Markowski T., Szlachta J., Węcławowicz G., Zalewski J., Zaucha J., 2010, Ekspercki Projekt Koncepcji Przestrzennego Zagospodarowania Kraju do roku 2033, Studia KPZK PAN, 128, Warszawa.

Kowalczyk K., Rosik P., 2015, Wykorzystanie infrastruktury przez przewoźników kolejowych w obsłudze połązeń międzyaglomeracyjnych, Logistyka, 3, s. 5350-5357.

Kwarciński T., 2012, Dostępność transportowa jako paradygmat ksztattujq̨cy wielkość przewozów w publicznym transporcie pasażerskim, Logistyka, 2, s. 169-173.

L'Hostis A., 2013, Contactability in Accessibility Instruments for Planning Practice, COST action Accessibility Instruments, s. 85-90.

L'Hostis A., Liu L., Leysens T., 2017, Using contact potential measurements to analyse future intercity links made possible by the Tours-Bordeaux High-Speed Rail line, National Committee of Geography of Belgium. 
López E., Gutierrez J., Gómez G., 2008, Measuring Regional Cohesion Effects of Large-scale Transport Infrastructure Investments: An Accessibility Approach, TRANSyT-UPM, Centre for Transport Research, Universidad Politécnica de Madrid.

Meijers E., 2005, Polycentric Urban Regions and the Quest for Synergy: Is a Network of Cities more than the Sum of the Parts?, Urban Studies, 42, s. 765-781.

Meijers E., 2007, Synergy in Polycentric Urban Regions. Complementarity, Organizing Capacity and Critical Mass, Sustainable Urban Areas, 13.

Nazari Adli S., Chowdhury S., Shiftan Y., 2019, Justice in public transport systems: A comparative study of Auckland, Brisbane, Perth and Vancouver, Cities, 90, s. 88-99.

PLK, 2020, Mapa inwestycji ujętych w Krajowym Programie Kolejowym, PKP Polskie Linie Kolejowe SA, http://www.plk-inwestycje.pl/\#/(28.05.2020).

Rosik P., 2012, Dostępność lqqdowa przestrzeni Polski w wymiarze europejskim, IGiPZ PAN, Warszawa.

Rosik P., Pomianowski W., Goliszek S., Stępniak M., Kowalczyk K., Guzik R., Kołoś A., Komornicki T., 2017, Multimodalna dostępność transportem publicznym gmin w Polsce, Prace Geograficzne, 258, IGiPZ PAN, Warszawa.

Rosik P., Stępniak M., Komornicki T., 2015, The decade of the big push to roads in Poland: impact on improvement in accessibility and territorial cohesion from a policy perspective, Transport Policy, 37, s. 134-146.

Rydzewski T., 2002, Komunikacja jako miernik powiqzań przestrzennych na przykładzie Polski, [w:] J. Wendt (red.), Wybrane zagadnienia geografii transportu, Uniwersytet Szczeciński, Szczecin, s. 34-42.

Spiekermann K., Schürmann C., 2007, Update of selected potential accessibility indicators. Final report, Spiekermann \& Wegener, Urban and Regional Research (S\&W), RRG Spatial Planning and Geoinformation.

Starikova A., 2018, Population mobility in Bavaria: spatio-temporal features and migration flows in the early 21st century, Europa XXI, 34, IGiPZ PAN, s. 59-78.

Stępniak M., Rosik P., Komornicki T., 2013, Accessibility patterns: Poland case study, Europa XXI, 24, IGiPZ PAN, Warszawa, s. 151-168.

Stępniak M., Wiśniewski R., Goliszek S., Marcińczak S., 2017, Dostępność przestrzenna do usług publicznych w Polsce, Prace Geograficzne, 261, IGiPZ PAN, Warszawa.

Strategia Rozwoju Transportu do 2020 roku (z perspektywq do 2030 roku), 2013, Ministerstwo Transportu, Budownictwa i Gospodarki Morskiej, Warszawa.

Taylor Z., 2007, Rozwój i regres sieci kolejowej w Polsce, Monografie, 7, IGiPZ PAN, Warszawa.

UTK, 2019, Przewozy pasażerskie w 2017 roku, Urząd Transportu Kolejowego, Warszawa.

Ważna A., 2013, Wykorzystanie badań nad dostępnościq transportowq do oceny wartości czasu w transporcie, [w:] E. Walińska (red.), Współczesne problemy finansów, rachunkowości i zarzqdzania, Ekonomia i Zarządzanie w Teorii i Praktyce, 7, Uniwersytet Łódzki, s. 319-332.

Wiśniewski S., 2015, Powiqzania miast województwa łódzkiego w systemie kolejowego transportu zbiorowego w świetle potencjału komunikacyjnego, Prace Geograficzne, 140, s. 25-38.

Wiśniewski R., Komornicki T., 2015, The influence of Road corridors on the social condition of adjacent areas, Europa XXI, 28, IGiPZ PAN, s. 52-71.

Zhao M., Derruder B., Huang J., 2017, Examining the transition processes in the Pearl River Delta polycentric mega-city region through the lens of corporate networks, Cities, 60, s. 147-155. 


\section{Summary}

Daily accessibility as one of the measures of transport accessibility is an indicator that can be used, i.a. as relations between a given area's transport system and spatial planning are analysed. The indicator provides a broad field for assessing the effectiveness of the transport system and spatial planning operating at a given time, while simultaneously indicating directions by which these may be improved. The main aim of the work detailed here was to assess whether and to what extent the current road system, as well as the layout of railway lines and connections, creates positive conditions for the development of the network configuration of Polish metropolises. In terms of application, the aim is to assess the level of implementation of the polycentric metropolitan network referred to in the KPZK 2030 document (i.e. Poland's National Spatial Planning Concept through to the year 2030).

The paper thus presents an attempt to determine the potential for mutual functional and spatial connections to be established or reinforced within Poland's system of voivodeship cities. That estimation of potential was based on analysis of daily (i.e. within-the-day) accessibility among the cities in question. The measurement of daily accessibility was based on the time of individual (car) travel or that involving rail transport. The analysis further included three variants for travel within the space of a given day (i.e. with 4, 6 or 8 hours available at the destination). This allowed for the development of a synthetic index of daily accessibility by which to characterise selected voivodship cities, which might then be classified in terms of their potential for establishing functional and spatial interrelatedness. The results of the research conducted offer a broad insight into the potential for selected voivodship cities to benefit from participation in the inter-agglomeration network. Moreover, thanks to our research, it was possible to identify peripheral areas (in which development potential was relatively lower) - which therefore require the kind of additional activation and compensatory action foreseen by KPZK 2030. Such actions should certainly relate to improved transport accessibility among the system's largest centres. 